\title{
The Importance of Antiviral Prophylaxis in Anti Hbc Positive Patients with Autologous Haematopoietic Stem Cell Transplantation
}

\section{Otolog Hematopoetik Kök Hücre Nakli Olan Anti Hbc Pozitif Hastalarda Antiviral Profilaksinin Önemi}

\author{
Sabahat Çeken ${ }^{1}$, Merih Kızıl Çakar², Gülşen İskender', Duygu Mert', Habip Gedikª , Göknur Yapar \\ Toros $^{1}$, Mehmet Sinan Dal ${ }^{2}$, Fevzi Altuntas², Mustafa Ertek ${ }^{1}$ \\ ${ }^{1}$ Dr.Abdurrahman Yurtaslan Ankara Onkoloji Eğitim ve Araştırma Hastanesi, Enfeksiyon Hastalıkları ve Klinik \\ Mikrobiyoloji Kliniği, Ankara, Türkiye \\ ${ }^{2}$ Dr.Abdurrahman Yurtaslan Ankara Onkoloji Eğitim ve Araştırma Hastanesi, Hematoloji Kliniği, Ankara, \\ Türkiye \\ ${ }^{3}$ Bakırkoy Sadi Konuk Eğitim ve Araştırma Hastanesi, Enfeksiyon Hastalıkları ve Klinik Mikrobiyoloji Kliniği, \\ İstanbul, Türkiye
}

Dergiye Ulaşma Tarihi: 16.09.2020 Dergiye Kabul Tarihi: 24.11.2020 Doi: 10.5505/aot.2020.81894

\section{ÖZET}

GİRIŞ ve AMAÇ: Bu çalışmanın amacı, otolog hematopoietik kök hücre nakli (HSCT) olan hastalarda HBV reaktivasyonunu etkileyen faktörleri araştırmak ve HBs Ag negatif/AntiHbc IgG pozitif hastalarda hepatit profilaksisinin gerekliliğini değerlendirmektir.

YÖNTEM ve GEREÇLER: Çalışma, 500 yataklı bir eğitim hastanesinde yapılan retrospektif gözlemsel kohort çalışmasıdır. HSCT için immünosüpresif tedavi alması planlanan hastalar $\mathrm{Hbs} \mathrm{Ag}$, Anti $\mathrm{HBs}$ ve Anti $\mathrm{Hbc} \operatorname{IgG}$ bakılarak HBV açısından tarandı. Çalışma popülasyonu Mayıs 2012 - Aralık 2018 tarihleri arasında hastanemizde otolog HSCT olan ve Anti Hbc IgG için pozitif olan hastalardan oluşmaktaydı.

BULGULAR: HSCT uygulanan 328 hastanın HBs Ag, Anti Hbs ve Anti Hbc IgG test sonuçları incelendi. Ortanca yaş 59'du (Aralık: 23-66 yaş) ve hastaların 63'ü (\% 65,6) erkekti. HBs-Ag negatif / Anti Hbc IgG pozitif hastaların beşinde (gizli hepatit) HBV-DNA pozitiflĭgi saptandı. Bu hastalara nükleoz(t)id (NA) profilaksisi uyguland. Hbs Ag negatif hastaların toplam 52'si (\% 61.9) NA profilaksisi aldı. Herhangi bir antiviral profilaksi almayan 32 hastanın dördünde (\% 12.5), nakilden sonraki ortanca 9. ayda (6-13 ay) HBV reaktivasyonu görüldü. TARTIŞMA ve SONUÇ: HBs Ag negatif/anti-HBc IgG pozitif olan otolog HSCT alıcılarına, HBV reaktivasyonu riski göz önüne alınarak, antiviral profilaksi uygulanmalıdır. Lammivudin (LAM) bu hastalar için profilaksideki potent NA'lar kadar etkilidir ve 12 aylık süre profilaksi için yeterlidir

Anahtar Kelimeler: Hepatit B virüsü, HBV reaktivasyonu, Otolog hematopoietik kök hücre nakli, antiviral profilaksi

\section{ABSTRACT}

INTRODUCTION: The aim of the study is to investigate the factors affecting HBV reactivation in patients with autologous hematopoietic stem cell transplantation (HSCT) and to evaluate the necessity of hepatitis prophylaxis in $\mathrm{HBs} \mathrm{Ag}$ negative/AntiHbc $\mathrm{IgG}$ positive patients

METHODS: The study is a retrospective observational cohort study conducted in a 500-bed teaching hospital. Patients who were planned to get immunosuppressive therapy for malignancy were screened for HBV by Hbs $\mathrm{Ag}$, Anti $\mathrm{HBs}$, and Anti $\mathrm{Hbc} \operatorname{IgG}$ levels. The study population was consisted of patients, who had autologous HSCT in our hospital between May 2012 and December 2018, and were positive for Anti Hbc IgG.

RESULTS: HBs Ag, Anti Hbs, and Anti Hbc IgG test results of 328 patients who underwent HSCT were examined. The median age was 59 years (Range: 23-66 years) and $63(65.6 \%)$ of them were male. HBV-DNA was detected in low values in five (5.9\%) of HBs Ag negative/Anti Hbc IgG positive patients (occult hepatitis). Nucleot(s)ide analogue (NA) prophylaxis was administered to those patients. Totally 52 (61.9\%) of the Hbs Ag negative patients received NA prophylaxis. HBV reactivation occurred in four (12.5\%) of 32 patients who did not receive any antiviral prophylaxis, in a median of 9 months (6-13 months) after transplantation 
DISCUSSION AND CONCLUSION: Antiviral prophylaxis should be administered to autologous HSCT patients, who are $\mathrm{HBs} \mathrm{Ag}$ negative/anti-HBc $\operatorname{IgG}$ positive, taking into consideration the risk of $\mathrm{HBV}$ reactivation. Lamivudine (LAM) is as effective as the potent NAs in the prophylaxis for those patients, and 12 months is enough for prophylaxis.

Keywords: Hepatit B virus, HBV reactivation, autologous HSCT, antiviral prophylaxis

\section{Introduction}

Hepatitis B is a common public health problem worldwide. Approximately 2 billion people have been exposed to the Hepatitis B virus (HBV), and 240 million of them are chronically infected $(1,2)$. Hepatitis B reactivation may occur even after years of HBsAg loss due to the persistence of covalently closed circular DNA of the virus in hepatocytes in patients with a resolved infection under certain conditions (3). Hepatitis $\mathrm{B}$ reactivation can occur asymptomatic, with only reappearance or increase of levels of HBV-DNA in the blood, as well as in different clinical pictures, including acute hepatitis and fulminant liver failure. It may even cause death (4). The treatment of the patient's primary disease may also be disrupted, as chemotherapy is discontinued due to $\mathrm{HBV}$ reactivation. Therefore, all candidates for immunosuppressive therapy should be screened for HBV infection by checking HBsAg, anti-HBs, and anti-HBc IgG before the treatment (5). Patients who are anti-HBc IgG positive should also be tested for HBVDNA levels and patients with positive HBVDNA levels should get antiviral prophylaxis with nucleos(t)ide analogs (NAs). In patients with negative $\mathrm{HBs} \mathrm{Ag}$ and HBV-DNA, prophylaxis decision is made by the level and duration of the immunosuppressive therapy (2).

HBV reactivation can develop in HSCT recipients as they receive profound and prolonged immunosuppressive therapy, especially in allogeneic HSCT (2). However, data about autologous HSCT patients are limited.

Our study aims to investigate the factors affecting HBV reactivation in patients with autologous HSCT and to evaluate the necessity of hepatitis prophylaxis in $\mathrm{HBs} \mathrm{Ag}$ negative and AntiHbc IgG positive patients. Also, the clinical features and treatment response of patients with HBV reactivation will be evaluated.

\section{Methodology}

This is a retrospective observational cohort study conducted in a 500-bed teaching hospital. Patients who were planned to get immunosuppressive therapy for malignancy were screened for HBV by Hbs Ag, Anti HBs, and Anti Hbc IgG levels. Patients with positive anti-HBc IgG were referred to the Department of Infectious Diseases. The patients either received an antiviral treatment/prophylaxis or were followed without treatment according to the HBs Ag positivity, HBV-DNA level and the type, and duration of the immunosuppressive treatment.

Antiviral prophylaxis was administered one week before the immunosuppressive therapy, if that was possible, or at least on the same day. Patients, who did not receive prophylaxis, were followed up with HBV-DNA at least once every 3 months during, and one year after the completion of their immunosuppressive treatment. Patients, who received antiviral prophylaxis, were also followed up with HBVDNA every 3-6 months for 1 year after discontinuation of the drug.

The study was carried on the Anti $\mathrm{Hbc}$ IgG positive patients, who had autologous HSCT in our hospital between May 2012 and December 2018. The data of the patients were recorded retrospectively from the hospital automation system and the patient files. Patients, who were older than 17 years and followed up for at least one year after autologous HSCT, were included in the study. Exclusion criteria were a negative test for anti-HBc IgG and to be under 17 years old. Patients, who could not be followed up for one year after transplantation for various reasons, were not included in the study either. Demographic data such as age and gender of the patients, underlying disease, and the conditioning regimen used for transplantation were recorded. Laboratory tests like $\mathrm{HBe} \mathrm{Ag}$, Anti HBe, HBV-DNA level, and Anti-HBs titer were also recorded.

Serological tests were performed by Cobas Roche Diagnostics using an electrochemiluminescence immunological assay. HBV-DNA quantification by real-time 
polimerase chain reaction (PCR) was performed in Rotor-Gene Q (Qiagen, Germany). The analytical detection limit of HBV DNA is $31.6 \mathrm{IU} / \mathrm{mL}$ (linear range: $31.6-$ $20000000 \mathrm{IU} / \mathrm{mL}$ ).

Anti-HBs titer $\geq 10 \mathrm{IU}$ was sustained as positive. The patients with a value of Anti-HBs titer $\geq 100$ IU were evaluated additionally, to assess whether this titer was protective to prevent reactivation. If antiviral prophylaxis was initiated, the name of the antiviral drug, HBV reactivation status, the administered treatments after reactivation, response to the treatment and follow-up time (months) were also recorded.

HBs Ag positive/Anti-HBc IgG positive and $\mathrm{HBs} \mathrm{Ag}$ negative/Anti-HBc IgG positive patients were evaluated as two separate groups. All of the autologous HSCT patients with positive $\mathrm{HBs} \mathrm{Ag}$ received antiviral prophylaxis/therapy, while patients who were Hbs Ag negative, did not have a standard procedure until 2016. For this reason, while some patients received prophylaxis, some were followed without prophylaxis.

Definitions:

HBV reactivation: $\mathrm{HBs}$ Ag seroconversion (positive when previously negative) or $\geq 10$ fold increase HBV DNA level

Hepatic exacerbation: An increase in alanine aminotransferase (ALT) levels> 3 times the upper limit of normal or $>100 \mathrm{IU} / \mathrm{L}$

Severe hepatitis: An increase in ALT levels > 10 timesthe upper limit of normal, or an increase in total bilirubin $>1.5$ times the upper limit of normal $(6,7)$.

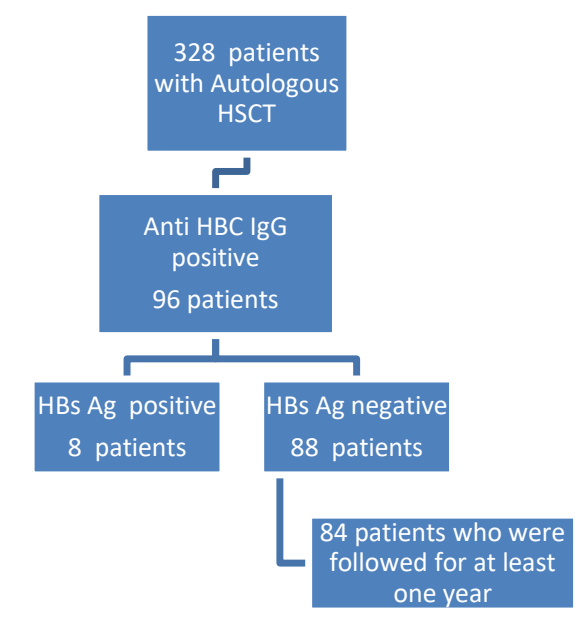

Figure -1: The serological status of patients included in the study
Clinical data, laboratory values, antiviral drugs used for antiviral treatment, and the outcome of the treatment of the patients with HBV reactivation was recorded. Local ethics committee approval was received. (202006/673)

Statistics:

The data were analyzed by SPSS 22.0 (Chicago, IL, USA). The continuous variables are described as the mean \pm the standard deviation and the range. The percentages were described up to three decimals. The Chisquared test or Fischer' s exact test was carried out to analyze the nominal variables.P-value $<0.05$ was considered as significant

\section{Results:}

In the study, $\mathrm{HBs} \mathrm{Ag}$, Anti Hbs, and Anti $\mathrm{Hbc}$ IgG test results of 328 patients who underwent HSCT were examined. The median age was 59 years (Range: 23-66 years), Sixty-three $(65.6 \%)$ of the patients were male. The underlying malignancies of patients were multiple myeloma (MM) (65.6\%), nonHodgkin lymphoma (NHL) (20.8\%), and Hodgkin lymphoma (HL) (10.4\%), respectively. Anti-HBc IgG was positive in 96 (29.2\%) the patients and HBs Ag was positive in eight $(8.3 \%)$ of the 96 patients, whereas 50 $(52 \%)$ of them had anti-HBs positivity. HBe $\mathrm{Ag}$ was positive in only one patient and 35 of them were anti-HBe positive. The demographic data and clinical features of those patients were summarized in Table-1.

Five of eight $\mathrm{HBs} \mathrm{Ag}$ positive patients were receiving antiviral drug due to chronic hepatitis B (CHB) before admission. TDF was administered to the remaining three patients for prophylaxis. HBV reactivation did not occur in those patients, except one patient who discontinued TDF at $11^{\text {th }}$ month after HSCT. The findings of $\mathrm{HBs} \mathrm{Ag}$ positive patients were summarized in Table- 2 . 
Table-1: Characteristics of the Anti-HBc IgG Positive Patients

\begin{tabular}{|c|c|}
\hline & $(n=96)$ \\
\hline Age, median (min-max) & $59(23-66)$ \\
\hline Male sex, $n(\%)$ & $63(65.6)$ \\
\hline $\begin{array}{l}\text { Malignity } \\
\text { HodgkinLymphoma, n(\%) } \\
\text { Non Hodgkin Lymphoma, n(\%) } \\
\text { Multipla Miyeloma, n(\%) } \\
\text { Solid Tumor, } n(\%)\end{array}$ & $\begin{array}{l}10(10.4) \\
20(20.8) \\
63(65.6) \\
3(3.1)\end{array}$ \\
\hline HBsAg positive, n (\%) & $8(8.3)$ \\
\hline HBeAg positive, $n$ (\%) & $1(1)$ \\
\hline Anti Hbe positive, n (\%) & $35(36.4)$ \\
\hline Anti HBs positive, n (\%) & $50(52)$ \\
\hline
\end{tabular}

In the first year of transplantation, four patients from $\mathrm{HBs} \mathrm{Ag}$ negative group died of various reasons other than HBV reactivation, so 84 HBs Ag negative patients were included in the study. The median age of these patients was 55 years (range: 20-69 years) Fifty-eight (69\%) of the patients of them were male. HBV-DNA was detected in low values in $5.9 \%$ of those patients (occult hepatitis). NA prophylaxis was administered to those patients due to occult hepatitis. Totally 52 (61.9\%) of the $\mathrm{Hbs} \mathrm{Ag}$ negative patients received NA prophylaxis. Twenty-eight (33.3\%), 20 (23.8\%), and 4 $(4.7 \%)$ patients received lamivudine (LAM), tenofovir disoproxil fumarate (TDF) and entecavir (ETV), for prophylaxis, respectively. All of the drugs were well tolerated and there were no recorded serious side effects that caused discontinuation of the treatment.

HBV reactivation occurred in four of 32 patients who did not receive any antiviral prophylaxis, in a median of 9 months (6-13 months) after transplantation. The age of patients with HBV reactivation was between 45-64 years and three of them were male. The underlying diseases of the three patients were multiple myeloma (MM) and one was NHL. Severe hepatitis developed in three patients, but none of them died.

Three patients received ETV and one received LAM for the treatment of HBV reactivation. The development of HBV reactivation in the prophylaxis group and non-prophylaxis group were found statistically different $(p=0.024)$.The age, gender, underlying malignancy, given regimen, and anti-HBs positivity of the patients were not statistically different for both groups in terms of reactivation. The clinical and laboratory findings of the prophylaxis group and nonprophylaxis group were summarized in Table3.

The patients were followed up for $37.75 \pm$ 21.27 months. Three patients remained to be $\mathrm{HBs} \mathrm{Ag}$ positive during the follow-up. One of the patients became $\mathrm{HBs} \mathrm{Ag}$ negative and Anti-HBs positive in the sixth month of the treatment. Clinical and laboratory findings of the patients with $\mathrm{HBV}$ reactivation were summarized in Table-4 
Table-2: The findings of HBsAg Positive Patients

\begin{tabular}{|c|c|c|c|c|c|c|c|c|}
\hline $\begin{array}{c}\text { Patient } \\
\text { Number }\end{array}$ & Age & Sex & Malignity & $\begin{array}{l}\text { HBV DNA } \\
\text { (copies/ml) } \\
\text { Before } \\
\text { HSCT }\end{array}$ & $\begin{array}{l}\text { Former } \\
\text { NA } \\
\text { Therapy }\end{array}$ & $\begin{array}{l}\text { NA therapy } \\
\text { during } \\
\text { HSCT }\end{array}$ & $\begin{array}{l}\text { Follow- } \\
\text { up time } \\
\text { (months) }\end{array}$ & $\begin{array}{l}\text { HBV } \\
\text { reactivation }\end{array}$ \\
\hline P1 & 65 & M & MM & 0 & LAM & LAM & 36 & No \\
\hline P2 & 68 & M & NHL & 0 & LAM & LAM & 71 & No \\
\hline P3 & 30 & M & NHL & 0 & TDF & TDF & 24 & No \\
\hline P4 & 69 & M & NHL & 4000 & LAM & TDF & 26 & No \\
\hline P5 & 62 & F & MM & 0 & LAM & LAM & 4 (Died) & No \\
\hline P6 & 29 & F & NHL & 519 & - & TDF & 24 & No \\
\hline P7 & 24 & M & HL & 153 & - & TDF & 19 & No \\
\hline P8 & 64 & F & MM & 5755 & - & $\begin{array}{c}\text { TDF } \\
\text { (discontinued) }\end{array}$ & 19 & Yes \\
\hline
\end{tabular}

M: Male, F: Female, MM: Multipla Miyeloma NHL: Non-Hodgkin Lymphoma: HL Hodgkin Lymphoma, LAM: Lamivudine, TDF: Tenofovir disoproxil fumarate, HBV: Hepatitis B virus 
Table-3:The findings of the HBs Ag negative/Anti-HBc IgG positive patients with or without HBV Reactivation

\begin{tabular}{|c|c|c|c|c|}
\hline & $\begin{array}{l}\text { Total } \\
(n=84)\end{array}$ & $\begin{array}{l}\text { Patients without HBV } \\
\text { Reactivation }(n=80)\end{array}$ & $\begin{array}{l}\text { Patients with HBV } \\
\text { Reactivation }(n=4)\end{array}$ & $\mathbf{p}$ \\
\hline Age, median (min-max) & $55(20-69)$ & $55(20-69)$ & $63(45-64)$ & 0,326 \\
\hline Male sex, $n(\%)$ & $58(69)$ & $55(68.7)$ & $3(75)$ & 0,845 \\
\hline $\begin{array}{l}\text { Malignite: } \\
\text { Hodgkin lenfoma, n (\%) } \\
\text { Non Hodgkin lenfoma, n (\%) } \\
\text { Multipl Miyelom, n }(\%) \\
\text { Solid Tumor, n }(\%)\end{array}$ & $\begin{array}{c}9(10.7) \\
14(16.6) \\
58(69) \\
3(3.5)\end{array}$ & $\begin{array}{c}9(11) \\
13(16) \\
55(68.7) \\
3(3.7)\end{array}$ & $\begin{array}{c}0(0) \\
1(25) \\
3(75) \\
0(0)\end{array}$ & 0.719 \\
\hline $\begin{array}{l}\text { Conditioning regimen } \\
\text { Melfalan, n(\%) } \\
\text { BEAM, n(\%) } \\
\text { TECA, n(\%) } \\
\text { CY-TBI, n(\%) }\end{array}$ & $\begin{array}{c}57(67.8) \\
22(26.1) \\
3(3.5) \\
2(2.3)\end{array}$ & $\begin{array}{c}54(67.5) \\
2126.2() \\
3(3.7) \\
2(2.5)\end{array}$ & $\begin{array}{c}3(75) \\
1(25) \\
0(0) \\
0(0)\end{array}$ & 0.908 \\
\hline Occult hepaitis, n(\%) & $5(5.9)$ & $5(6.2)$ & $0(0)$ & 0.779 \\
\hline HBeAg positive, n (\%) & $0(0)$ & $0(0)$ & $0(0)$ & \\
\hline Anti Hbe positive, n (\%) & $25(29.7)$ & $24(30)$ & $1(25)$ & 0.657 \\
\hline Anti HBs positive ( $\geq 10 \mathrm{IU}), \mathrm{n}(\%)$ & $48(57.1)$ & $46(57.5)$ & $2(50)$ & 0.27 \\
\hline Anti HBs $\geq 100$, n(\%) & $25(29.7)$ & $23(28.7)$ & $2(50)$ & 0.574 \\
\hline $\begin{array}{l}\text { Patients with NA Prophylaxis, } \\
(\%)\end{array}$ & $52(61.9)$ & $52(65)$ & $0(0)$ & 0.179 \\
\hline $\begin{array}{l}\text { Drug for Prophylaxis: } \\
\text { No prophylaxis } \\
\text { Lamivudin } \\
\text { Tenofovir Disoproxil Fumarate } \\
\text { Entecavir }\end{array}$ & $\begin{array}{c}32(38,1) \\
28(33.3) \\
20(23.8) \\
4(4.7)\end{array}$ & $\begin{array}{c}28(35) \\
28(35) \\
20(25) \\
4(5)\end{array}$ & $\begin{array}{c}4(100) \\
0(0) \\
0(0) \\
0(0)\end{array}$ & 0.024 \\
\hline Follow-up time (months) & $37,75 \pm 21,27$ & $38,01 \pm 21,41$ & $30,75 \pm 19,61$ & 0.503 \\
\hline
\end{tabular}


Tablo-4: The findings of Patients With HBV Reactivation

\begin{tabular}{|c|c|c|c|c|}
\hline & R1 & $\mathbf{R 2}$ & $\mathbf{R 3}$ & R4 \\
\hline Age & 64 & 63 & 61 & 45 \\
\hline Sex & Female & Male & Male & Male \\
\hline Maligniity & $\mathrm{MM}$ & MM & MM & NHL \\
\hline Conditioning Regimen & Melfelan & Melfelan & Melfelan & BEAM \\
\hline HBV Prophylaxis & No & No & No & No \\
\hline $\begin{array}{l}\text { Reactivation time } \\
\text { (months) }\end{array}$ & 13 & 6 & 8 & 9 \\
\hline $\begin{array}{l}\text { Serology during HBV } \\
\text { Reactivation } \\
\text { HBsAg } \\
\text { Anti HBcIgM } \\
\text { HBeAg } \\
\text { Anti HBe } \\
\text { Anti HBs }\end{array}$ & $\begin{array}{l}\text { Positive } \\
\text { Positive } \\
\text { Positive } \\
\text { Negative } \\
\text { Positive }\end{array}$ & $\begin{array}{l}\text { Positive } \\
\text { Negative } \\
\text { Positive } \\
\text { Negative } \\
\text { Negative }\end{array}$ & $\begin{array}{l}\text { Positive } \\
\text { Positive } \\
\text { Negative } \\
\text { Positive } \\
\text { Negative }\end{array}$ & $\begin{array}{l}\text { Positive } \\
\text { Positive } \\
\text { Positive } \\
\text { Negative } \\
\text { Negative }\end{array}$ \\
\hline HBV DNA (copy/ml) & $4 \times 10^{4}$ & $1.4 \times 10^{8}$ & $1.6 \times 10^{4}$ & $3.2 \times 10^{6}$ \\
\hline ALT & 696 & 194 & 2554 & 713 \\
\hline AST & 416 & 152 & 654 & 567 \\
\hline Total bilirubin & 5 & 0.55 & 14.3 & 2.5 \\
\hline Antiviral treatment & $\begin{array}{l}\text { Lamivudin } 100 \\
\mathrm{mg}\end{array}$ & Entecavir $0.5 \mathrm{mg}$ & Entecavir $0.5 \mathrm{mg}$ & Entecavir $0.5 \mathrm{mg}$ \\
\hline $\begin{array}{ll}\begin{array}{l}\text { Follow-up } \\
\text { (month) }\end{array} & \text { time } \\
\end{array}$ & 23 & 15 & 58 & 30 \\
\hline Outcome & $\begin{array}{c}\text { HBV DNA } \\
\text { Negative } \\
\text { LFTs: Normal } \\
\text { HBsAg Positive } \\
\text { Anti HBs } \\
\text { Positive }\end{array}$ & $\begin{array}{c}\text { HBV DNA } \\
\text { Negative } \\
\text { LFTs: Normal } \\
\text { HBsAg Positive } \\
\text { Anti HBs negative }\end{array}$ & $\begin{array}{c}\text { HBV DNA } \\
\text { Negative } \\
\text { LFTs: Normal } \\
\text { HBs Ag neg } \\
\text { Anti HBs positive }\end{array}$ & $\begin{array}{c}\text { HBV DNA } \\
\text { Negative } \\
\text { LFTs: Normal } \\
\text { HBsAg positive } \\
\text { Anti HBs negative }\end{array}$ \\
\hline $\begin{array}{l}\text { Mortality Related to } \\
\text { HBV Reactivation }\end{array}$ & No & No & No & No \\
\hline
\end{tabular}

\section{Discussion}

According to the world health organization (WHO), Turkey is in the middle endemicity region, like most of the Mediterranean countries, the Middle East, and some countries in South America, where HBV prevalence is between $2-8 \%$ in terms of HBV.

HBs Ag prevalence was reported to be $4-5 \%$ in blood donors in 2011 and it was reported as $2 \%$ in another recent study $(8,9)$. In a study investigating the HBV seroprevalence in Turkey, HBs Ag was reported to be positive in $4 \%$ of the population. Anti-HBc IgG was positive in $30.6 \%$ of them and Anti-HBs was $31.9 \%$ of the people in this study (10). In a study conducted in cancer patients in 2011, Hbs Ag, Anti HBs and Anti-HBc IgG seropositivity were reported to be $4.2 \%$, $34.6 \%$ and $38.4 \%$, respectively (11). In our study, HBs Ag positivity was $2.4 \%$ and Anti$\mathrm{HBc} \operatorname{IgG}$ of $29.2 \%$. The prevalence of $\mathrm{HBs} \mathrm{Ag}$ in our study was lower than those in the previous studies. This might be attributed to the positive effect of the hepatitis B vaccination program in Turkey since 1998 (12).

HBV-DNA was found to be positive $5.9 \%$ of patients with resolved HBV infection, in our study. Those rates were reported to be between $5-22 \%$ in different studies $(13,14)$.

In a study conducted in Korea, MM was reported to be an underlying disease and a risk factor for seroconversion after a resolved $\mathrm{HBV}$ infection in autologous HSCT patients (15). 
We did not find a significant difference between the underlying diseases of the patients who had reactivation.

$\mathrm{HBV}$ reactivation rate was reported as $6.5 \%$ in a study where MM patients with autologous HSCT were evaluated (13). In the study of Mikulska et al. HBV reactivation was detected in $14(10 \%)$ of 137 allogeneic HSCT patients with resolved HBV infection (16). Ramos et al reported HBV reactivation in $11.6 \%$ of 73 allogeneic HSCT patients within 3 years. The median time of reactivation was 17 months (range: 8 - 31 months) in this study (17). HBV reactivation occurred in a median of 9 months (range: 6-13 months) after transplantation in our study.

HBV reactivation time was 16 months after HSCT in median (range: 7-37 months) in the study of Varma et al, and 19 months (range:977 months) in the study of Mikulska et al $(13,16)$. Since the immunosuppression is prolonged because of GVHD prophylaxis in allogeneic HSCT patients, HBV reactivation may occur after years in allogeneic HSCT patients $(16,18)$.

Twenty-eight of HBs negative patients were under LAM as the prophylaxis and none of them had HBV reactivation during or after treatment in our study. LAM prophylaxis was administered to 63 allogeneic HSCT patients with resolved HBV infection in a study from Italy. Twenty-five percent of patients were under rituximab prophylaxis for the prevention of Epstein-Barr virus (EBV) associated posttransplant lymphoproliferative disease (PTLD). None of these patients had HBV reactivation under prophylaxis. Only one patient experienced reactivation after eight months of discontinuation of prophylaxis (19). LAM prophylaxis was effective against the HBV reactivation in HSCT patients with resolved HBV infection like in our study.

Although potent NAs, such as ENT, TDF, and TAF are recommended for the prophylaxis in HBs Ag positive patients in the EASL guideline, LAM is recommended for $\mathrm{HBs} \mathrm{Ag}$ negative patients (2). LAM could be preferred to decrease the cost related to antiviral prophylaxis in patients with autologous HSCT in whom immunosuppressive therapy is shorter than allogeneneic HSCT.

There are different suggested treatment durations between 6-18 months depending on the status and duration of the immunosuppression (2, 20-22). Our patients received NA prophylaxis for 12 months and HBV reactivation did not occur. Yoo et al reported $\mathrm{HBV}$ reactivation in $4.1 \%$ of 96 HSCT patients (59 allogeneic, 37 autologous), who had NA prophylaxis for a median of seven months. Therefore, short-term antiviral prophylaxis was reported to be not sufficient to prevent HBV reactivation (23). In a study conducted in autologous and allogeneic HSCT patients from our country, NA prophylaxis was administered to $\mathrm{HBs} \mathrm{Ag}$ negative patients, and no reactivation was reported, during the median follow-up duration of 21-months. Antiviral prophylaxis duration was not revealed in this study (24). The duration of antiviral prophylaxis was 12 months after cessation of immunosuppressive treatment in our study.

The limitation of our study is that it is a retrospective study, so that the data, such as the stage of the malignancy and the status of relapse after HSCT were not included.

\section{Conclusion:}

Antiviral prophylaxis should be administered to autologous HSCT patients, who are HBs Ag negative/anti-HBc IgG positive, taking into consideration the risk of $\mathrm{HBV}$ reactivation. LAM is as effective as the potent NAs in the prophylaxis for those patients, and 12 months is enough for prophylaxis.

There is no conflict of interest.

\section{References}

1. WHO Guidelines Approved by the Guidelines Review Committee (2015) Guidelines for the prevention, care, and treatment of persons with chronic hepatitis B infection. Geneva: World Health Organization

2. European Association for the Study of the Liver. (2017) EASL 2017 Clinical Practice Guidelines on the management of hepatitis $\mathrm{B}$ virus infection $\mathrm{J}$ Hepatol; 67: 370-98.

3. Raimondo G, Allain JP, Brunetto MR et al. (2008) Statements from the taormina expert meeting on occult hepatitis B virus infection. J Hepatol; 49: 652-657.

4. Liang R, Lau GK, Kwong YL (1999) Chemotherapy and bone marrow transplantation for cancer patients who are also chronic hepatitis B carriers: a review of the problem. J Clin Oncol.; 17(1):394-398.

5. L. Sarmati, M. Andreoni, G. Antonelli, W. Arcese, R. Bruno, N. Coppola, et al. (2017)

Recommendations for screening, monitoring, prevention, prophylaxis and therapy of hepatitis B virus reactivation in patients with haematologic 
malignancies and patients who underwent haematologic stem cell transplantation - a position paper. Clin Microbiol Infect; 23:935-940

6. Terrault NA, Lok ASF,McMahon BJ, Chang K, Hwang JP, Jonas MM, et al. (2018) Update on prevention, diagnosis, and treatment of chronic hepatitis B: AASLD 2018 hepatitis B guidance. Hepatology 2018;67:1560-99.

7. Hsu C, Tsou HH, Lin SJ, Wang MC, Yao M, Hwang WL,et al. (2014) Chemotherapy-induced hepatitis B reactivation in lymphoma patients with resolved HBV infection: a prospective study. Hepatology; 59: 2092-2100

8. Toy M, Önder FO, Wörmann T, Bozday1 AM, Schalm SW, Borsboom GJ, et al. (2011) Ageand region-specific hepatitis B prevalence in Turkey estimated using generalized linear mixed models: a systematic review. BMC Infect Dis; 11:337

9. S Tosun (2013), Epidemiology of viral hepatitis in Turkey: a meta-analysis of all published papers. F. Tabak, S. Tosun (Eds.), Viral hepatitis 2013, Tip publisher, Istanbul pp. 27-79

10. Tozun N, Ozdogan O, Cakaloglu Y, Idilman R, Karasu Z, Akarca U, et al. (2015) Seroprevalence of hepatitis $\mathrm{B}$ and $\mathrm{C}$ virus infections and risk factors in Turkey: a fieldwork TURHEP study. Clin Microbiol Infect; 21:1020-6

11. Kose S, Olmezoglu A, Gozaydin A, Ece G. (2011) Seroprevalence of hepatitis B and C among oncology patients in Turkey. J Health Popul Nutr. ;29(6):652-5

12. Aksaray N (2004) Türkiye'de Uygulanan Aş1 Takvimi. Turkiye Klinikleri J Pediatr-Special Topics; 2(3):340-2

13. Varma A, Biritxinaga L, Saliba RM, Stich M, Jauch SF, Afrough A, et al. (2017) Impact of Hepatitis B Core antibody seropositivity on the outcome of autologous hematopoietic stem cell transplantation for Multiple Myeloma. Biol Blood Marrow Transplant;23:581-587

14. Koo YX, Tan DS, Tan IB, Tao M, Chow WC, Lim ST (2010) Hepatitis B virus reactivation and role of antiviral prophylaxis inlymphoma patients with past hepatitis $b$ virus infection who are receiving chemoimmunotherapy. Cancer;116(1):115-21

15. Uhm JE, Kim K, Lim TK, Park B, Park SJ, Hong YS, et al (2007) Changes in serologic markers of hepatitis B following autologous hematopoietic stem cell transplantation.Medicine Biology of blood and marrow transplantation: journal of the American Society for Blood and Marrow Transplantation;13:463-468
16. Mikulska M, Nicolini L, Signori A, Rivoli G, Del Bono V, Raiola AM, et al. (2014) Hepatitis B reactivation in $\mathrm{HBsAg}$-negative/HBcAb-positive allogeneic haematopoietic stem cell transplant recipients: risk factors and outcome. Clin Microbiol Infect; 20(10):O694-701.

17. Ramos CA, Saliba RM, Silva LP, Khorshid O, Shpall EJ, Giralt S, et al. Resolved hepatitis B virus infection is not associated with worse outcome after allogeneic hematopoietic stem cell transplantation. Biol Blood Marrow Transplant. 2010; 16(5):686694.

18. Locasciulli A, Bruno B, Alessandrino EP, Meloni G, Arcese W, Ban $\neg$ dini G, et al. (2003) Hepatitis reactivation and liver failure in haemopoietic stem cell transplants for hepatitis B virus (HBV)/hepatitis $\mathrm{C}$ virus (HCV) positive recipients: a retrospective study by the Italian group for blood and marrow transplantation. Bone Marrow Transplant;31:295300

19. Zappulo E, Nicolini LA, Di Grazia, C, Dominietto A, Lamparelli T, Gualandi F, et al(2019) Efficacy of lamivudine prophylaxis in preventing hepatitis $\mathrm{B}$ virus reactivation in patients with resolved infection undergoing allogeneic SCT and receiving rituximab. Infection; 47:59-65

20. SandherrM, Hentrich $M$, von Lilienfeld-Toal $M$, Massenkeil G, Neumann S, Penack O, et al. (2015) Antiviral prophylaxis in patients with solid tumors and haematological malignancies - update of the Guidelines of the Infectious DiseasesWorking Party (AGIHO) of the German Society for Hematology and Medical Oncology (DGHO). Ann Hematol; 94:1441-1450

21. Aygen B, Demir AM, Gümüș M, Karabay O, Kaymakoğlu S, Köksal AŞ, et al. (2018) Immunosuppressive therapy and the risk of hepatitis B reactivation: Consensus report. Turk J Gastroenterol;29:259-269.

22. Sarin SK, Kumar M, Lau GK, Abbas Z, Chan HL, Chen CJ, et al. (2016) Asian-Pacific clinical practice guidelines on the management of hepatitis B: a 2015 update. Hepatol Int;10:1-98.

23. Yoo JJ, Cho EJ, Cho YY, Lee M, Lee DH, Cho Y, et al (2015) Efficacy of antiviral prophylaxis in $\mathrm{HBsAg}$-negative, anti-HBc positive patients undergoing hematopoietic stem cell transplantation Liver Int;35:2530-2536

24. Balkan A, Kırık MP, Gündeş İ, Şahin HH, Budeyri S, Balkan Y, et al. (2017) The frequency of hepatitis $\mathrm{B}$ virus reactivation in patients with bone marrow transplantation Eur J Ther;23:67-73 